\title{
Potocki-Shaffer syndrome
}

INSERM

\section{Source}

INSERM. (1999). Orphanet: an online rare disease and orphan drug data base. PotockiShaffer syndrome. ORPHA:52022

Potocki-Shaffer syndrome is characterized by multiple exostoses, parietal foramina, enlargement of the anterior fontanelle and occasionally intellectual deficit and mild cranio-facial anomalies. To date, 23 individuals from 14 families have been reported. The syndrome is caused by contiguous gene deletions on the short arm of chromosome 11 (11p11.2). 